Published in final edited form as:

Anal Chem. 2005 February 1; 77(3): 785-796.

\title{
Controlling Nonspecific Protein Adsorption in a Plug-Based Microfluidic System by Controlling Interfacial Chemistry Using Fluorous-Phase Surfactants
}

\author{
L. Spencer Roach, Helen Song, and Rustem F. Ismagilov* \\ Department of Chemistry, University of Chicago, 5735 South Ellis Avenue, Chicago, Illinois 60637
}

\begin{abstract}
Control of surface chemistry and protein adsorption is important for using microfluidic devices for biochemical analysis and high-throughput screening assays. This paper describes the control of protein adsorption at the liquid-liquid interface in a plug-based microfluidic system. The microfluidic system uses multiphase flows of immiscible fluorous and aqueous fluids to form plugs, which are aqueous droplets that are completely surrounded by fluorocarbon oil and do not come into direct contact with the hydrophobic surface of the microchannel. Protein adsorption at the aqueous-fluorous interface was controlled by using surfactants that were soluble in fluorocarbon oil but insoluble in aqueous solutions. Three perfluorinated alkane surfactants capped with different functional groups were used: a carboxylic acid, an alcohol, and a triethylene glycol group that was synthesized from commercially available materials. Using complementary methods of analysis, adsorption was characterized for several proteins (bovine serum albumin (BSA) and fibrinogen), including enzymes (ribonuclease A (RNase A) and alkaline phosphatase). These complementary methods involved characterizing adsorption in microliter-sized droplets by drop tensiometry and in nanoliter plugs by fluorescence microscopy and kinetic measurements of enzyme catalysis. The oligoethylene glycolcapped surfactant prevented protein adsorption in all cases. Adsorption of proteins to the carboxylic acid-capped surfactant in nanoliter plugs could be described by using the Langmuir model and tensiometry results for microliter drops. The microfluidic system was fabricated using rapid prototyping in poly(dimethylsiloxane) (PDMS). Black PDMS micro-fluidic devices, fabricated by curing a suspension of charcoal in PDMS, were used to measure the changes in fluorescence intensity more sensitively. This system will be useful for microfluidic bioassays, enzymatic kinetics, and protein crystallization, because it does not require surface modification during fabrication to control surface chemistry and protein adsorption.
\end{abstract}

\footnotetext{
This paper describes the biocompatibility of a plug-based microfluidic system obtained through control of surface chemistry the aqueous-fluorous interface. This microfluidic system uses multiphase flows of immiscible fluorous and aqueous liquids to form droplets (plugs) and to transport them with rapid mixing and no Taylor-like dispersion. ${ }^{1}$ We have previously used the system to measure enzyme kinetics ${ }^{2}$ and perform protein crystallization ${ }^{3-6}$ using submicroliter volumes of sample.

* To whom correspondence should be addressed. E-mail: r-ismagilov@uchicago.edu. SUPPORTING INFORMATION AVAILABLE

Additional information as noted in text: details of $\mathrm{R}_{\mathrm{f}}-\mathrm{OEG}$ extraction; drop tensiometry measurements for alkaline phosphatase at interfaces that presented each one of the three following surfactants: $\mathrm{R}_{\mathrm{f}}-\mathrm{COOH}, \mathrm{R}_{\mathrm{f}}-\mathrm{CH}_{2} \mathrm{CH} \mathrm{H}_{2} \mathrm{OH}$, or $\mathrm{R}_{\mathrm{f}}-\mathrm{OEG}$; tensiometry data for variable concentrations of fibrinogen at an interface that presents the $\mathrm{R}_{\mathrm{f}}-\mathrm{COOH}$ surfactant; tensiometry data for the adsorption of concentrated fibrinogen to a pure fluorocarbon interface, and also Selwyn's plots for alkaline phosphatase kinetics measured within a microfluidic device for plugs formed with each one of the following three surfactants: $\mathrm{R}_{f}-\mathrm{COOH}, \mathrm{R}_{\mathrm{f}}-\mathrm{CH}_{2} \mathrm{CH}_{2} \mathrm{OH}$, or $\mathrm{R}_{\mathrm{f}}-\mathrm{OEG}$. This material is available free of charge via the Internet at http://pubs.acs.org.
} 
Microfluidic systems are becoming increasingly useful for a range of analytical ${ }^{7-10}$ and chemical processes, ${ }^{11-13}$ especially systems relying on multiphase flows. Droplet-based microfluidic systems are being developed by a number of groups ${ }^{1,14-33}$ and are used for applications such as protein crystallization, ${ }^{3-6}$ nanoparticle synthesis, ${ }^{26-28}$ sorting droplets of different solutions, ${ }^{4,29}$ and organic-aqueous phase extraction. ${ }^{30}$ Microfluidic systems that rely on electrowetting have been employed for combinatorial fluid mixing 31,32 and mass spectrometry. ${ }^{33}$ All microfluidic systems operate at high surface-to-volume ratios; $11-13$ therefore, surface adsorption effects become much more important in microfluidic volumes (typically on the picoliter to nanoliter scale) than at higher volumes. ${ }^{34,35}$ A biologically inert surface that resists the adsorption of proteins must be presented to analytes in order to reliably perform biochemical transformations and analyses.

Protein adsorption to solid-water, ${ }^{36-38}$ oil-water, ${ }^{39,40}$ and air-water ${ }^{41}$ interfaces is a welldemonstrated phenomenon. Both hydrocarbon-water ${ }^{42}$ and fluorocarbon-water ${ }^{43}$ fluid-fluid interfaces cause protein adsorption and denaturation. We wished to characterize and to control nonspecific protein adsorption at the aqueous-fluorous interface. In a plug-based microfluidic device, aqueous plugs are completely surrounded by the fluorocarbon oil and do not contact the solid hydrophobic PDMS surface. Previous efforts to control nonspecific surface adsorption in microfluidics have focused on the solid-liquid interface, rather than the liquid-liquid interface. To prevent the adsorption of proteins, surfaces of silicon, plastic or metal can be modified chemically to present monolayers of oligoethylene glycol $36,37,44-50$ or betaine groups. ${ }^{51}$ A variety of polymeric surface coatings developed for capillary electrophoresis, such as polyacrylamide, poly(vinyl alcohol), and others, are useful in microfluidics. ${ }^{52}$ In addition, surfaces can be precoated with adhesion proteins, such as bovine serum albumin. 53,54 Oligoethylene glycol is the most common functional group used to prevent protein adsorption to interfaces. $36,37,44-50,55-65$ A technique has been presented that controls biomolecular adsorption in electrowetting-based fluidic chips. ${ }^{66}$ Ionic surfactants have been shown to prevent the adsorption of bovine serum albumin 67 and fibrinogen 68 at the air-water interface. Nonionic surfactants containing oligoethylene glycols have been used to displace $\beta$-casein at hydrocarbon-water interfaces. $60,69-71$

In this paper, we controlled protein adsorption in a plug-based microfluidic system by using surfactants to control the surface chemistry at the aqueous-fluorous interface. These surfactants are soluble in fluorous liquids, but are insoluble in aqueous solutions so that the surfactants do not interfere with the proteins in the bulk aqueous phase. One of these surfactants, containing a triethylene glycol functional group, was synthesized and also extracted from commercially available materials.

In this paper, we refer to microliter-sized drops formed without a microfluidic device as "droplets" and to nanoliter-sized drops formed in a microfluidic device as "plugs." We define a surface or interface as the boundary between two immiscible liquid solutions. We define a biocompatible interface as an interface that resists nonspecific protein adsorption. We characterized adsorption of proteins and of enzymes in this system in two ways. First, we measured the rate of protein adsorption at aqueous-fluorous interfaces by drop tensiometry. 42 Using this technique, the rate constant of adsorption was measured in microliter-sized droplets. Tensiometry has previously been used to study the adsorption of proteins and mixtures of proteins and surfactants to air-water and oil-water interfaces, and some surfactants have been found capable of displacing proteins from interfaces. ${ }^{72-74}$ To predict the rate of protein adsorption in nanoliter-sized plugs, we show how the rate of adsorption changes with the surface-to-volume ratio of the drop. Second, we qualitatively and quantitatively tested these predictions for adsorption within plugs by fluorescence microscopy. Qualitatively, we used fluorescently labeled proteins to visualize protein adsorption at the interface. Quantitatively, we used enzyme kinetics of ribonuclease A and alkaline phosphatase with fluorogenic 
substrates to evaluate deactivation of enzymes at the interface. For nonbiocompatible surfaces, enzymatic activity was reduced, as predicted. For biocompatible surfaces, reliable kinetic data were obtained.

\section{EXPERIMENTAL SECTION}

\section{Reagents and Solutions}

All aqueous solutions were prepared in 18-M $\Omega$ deionized water (Millipore, Billerica, MA) and were obtained from Sigma-Aldrich (St. Louis, MO) unless specified otherwise. Bovine serum albumin (BSA) and fibrinogen were dissolved in PBS buffer $(140 \mathrm{mM} \mathrm{NaCl}, 2.7 \mathrm{mM} \mathrm{KCl}, 10$ $\mathrm{mM} \mathrm{Na} 2-\mathrm{HPO}_{4}, 1.8 \mathrm{mM} \mathrm{KH}{ }_{2} \mathrm{PO}_{4}, \mathrm{pH}$ 7.2). Alexa Fluor 488 fibrinogen (obtained from Molecular Probes, Eugene, OR) was dissolved in PBS buffer and filtered with a $0.45 \mathrm{~m}$ PVDF syringe filter before use. The concentrations of nonfluorescent and fluorescent fibrinogen stock solution were quantified by UV-visible spectrometry at wavelengths of 280 and $488 \mathrm{~nm}$, respectively. Solutions of alkaline phosphatase (AP) and fluorescein diphosphate (FDP) were prepared in DEA buffer (1 M diethanolamine, $0.5 \mathrm{mM} \mathrm{MgCl}_{2}, \mathrm{pH} 10$ ). Solutions of ribonuclease A (RNase A, obtained from ICN Biomedicals, Irvine, CA) and RNaseAlert substrate (obtained from Ambion Inc., Austin, TX) were prepared in TE buffer (10 mM Tris (hydroxymethyl)aminomethane, $1 \mathrm{mM}$ disodium ethylenedi-amine tetraacetic acid, $\mathrm{pH}$ 7.5). All fluorous solutions were prepared in 3 M Fluorinert liquid FC-3283 (FC, obtained from 3M, St. Paul, MN). We purchased $1 H, 1 H, 2 H, 2 H$-perfluoro-1-octanol from Fisher Scientific (Pittsburgh, PA). Perfluorotetradecanoic acid and Zonyl FSO-100 were purchased from Aldrich.

\section{Preparation of Fluorous-Soluble Surfactant Solutions}

WARNING: Some perfluorinated surfactants are known to accumulate in biological tissue and cause hepatic and reproductive toxicity in laboratory animals. ${ }^{75}$ Proper care should be taken while handling these materials.

$\mathbf{R}_{\mathbf{f}}-\mathbf{C O O H}$ Fluorous Solution-In a typical preparation, perfluorotetradecanoic acid (65 $\mathrm{mg}, 0.091 \mathrm{mmol}$ ) (PFTDA) was shaken vigorously in FC-3283 (3 mL). The resulting suspension was filtered through a $0.22-\mathrm{m}$ filter. The absolute concentration of surfactant was determined by ${ }^{1} \mathrm{H}$ NMR. An internal standard of 10:1 (v/v) $1 H, 1 H, 2 H, 2 H$-perfluoro-1-octanol (PFO) in FC-3283 was loaded into a capillary (o.d. $1.28 \mathrm{~mm}$, i.d. $0.66 \mathrm{~mm}$ ), and the ends were sealed with a torch. This capillary was inserted into a NMR tube (inner diameter, $4.77 \mathrm{~mm}$ ) containing the saturated $\mathrm{R}_{\mathrm{f}}-\mathrm{COOH}$ filtrate. The ${ }^{1} \mathrm{H}$ NMR spectrum gave a broad peak (full width at half-maximum of $60 \mathrm{~Hz})$ for the acidic proton of PFTDA $\left(\mathrm{R}_{\mathrm{f}}-\mathrm{COOH}\right)$ with an integration of 0.60, $4.5 \mathrm{ppm}$ downfield from the sharp triplet for the methylene protons of $\mathrm{PFO}$ $\left(\mathrm{R}_{\mathrm{f}}-\mathrm{CH}_{2} \mathrm{CH}_{2} \mathrm{OH}\right)$ (integration of 0.99). Integration of peaks gave a solubility of PFTDA in FC-3283 of $7.0 \mathrm{mg} \mathrm{mL}^{-1}$. The PFTDA filtrate was diluted 1:500 (v/v) with FC-3283 to give a final PFTDA concentration of $14 \mathrm{~g} \mathrm{~mL}^{-1}$ and was used within $24 \mathrm{~h}$.

We assume that PFTDA $\left(\mathrm{R}_{\mathrm{f}}-\mathrm{COOH}\right)$ is deprotonated at the aqueous-fluorous interface. Surface $\mathrm{p} K_{1 / 2}$ values can be shifted by $3-4 \mathrm{p} K$ units from solution $\mathrm{p} K_{\mathrm{a}}$ values. ${ }^{76}$ The solution $\mathrm{p} K_{\mathrm{a}}$ of $\mathrm{R}_{\mathrm{f}}-\mathrm{COOH}$ is estimated to be $<1.0$ due to the strong electron withdrawal of the fluorinated alkane group, so $\mathrm{R}_{\mathrm{f}}-\mathrm{COOH}$ should be deprotonated at the $\mathrm{pH}$ of solutions (from 7 to 10) used in these experiments.

$\mathbf{R}_{\mathbf{f}}-\mathrm{CH}_{\mathbf{2}} \mathbf{C H}_{\mathbf{2}} \mathrm{OH}$ Fluorous Solution-FC-3283 and $1 \mathrm{H}, 1 \mathrm{H}, 2 \mathrm{H}, 2 \mathrm{H}$-perfluoro-1-octanol were mixed in a 10:1 (v/v) ratio; the mixture was used within $24 \mathrm{~h}$. 
$\mathbf{R}_{\mathbf{f}}$-OEG Fluorous Solution-Details on $\mathbf{R}_{\mathbf{f}}$-OEG extraction from Zonyl FSO-100 can be found in the Supporting Information.

$\mathbf{R}_{\mathbf{f}}$-OEG Synthesis-The molecule $\mathrm{CF}_{3}\left(\mathrm{CF}_{2}\right)_{8} \mathrm{CH}_{2} \mathrm{O}\left(\mathrm{CH}_{2} \mathrm{CH}_{2} \mathrm{O}\right)_{3} \mathrm{H}$ was synthesized according to Selve et al. ${ }^{77}$ with slight modifications.

\section{Triethyleneglycol Monooxy (trisdimethylamino) Phosphonium Hexafluorophosphate}

Triethylene glycol ( $0.97 \mathrm{~g}, 4.4 \mathrm{mmol}$, Acros Organics) and anhydrous carbon tetrachloride (1.9 $\mathrm{g}, 12 \mathrm{mmol})$ were dissolved in dry THF $(3.8 \mathrm{~mL})$ under $\mathrm{N}_{2}$ and cooled to $-40{ }^{\circ} \mathrm{C}$. A solution of hexamethylphosphorous triamide $(0.81 \mathrm{~g}, 4.7 \mathrm{mmol})$ in dry THF $(1 \mathrm{~mL})$ was added dropwise over the course of $2 \mathrm{~h}$. Stirring was continued for $30 \mathrm{~min}$. The reaction mixture was poured into $\mathrm{H}_{2} \mathrm{O}(10 \mathrm{~mL})$, extracted twice with $\mathrm{H}_{2} \mathrm{O}(2 \times 15 \mathrm{~mL})$, and washed with diethyl ether (30 $\mathrm{mL})$. A solution of potassium hexafluorophosphate $(1.84 \mathrm{~g}, 10 \mathrm{mmol})$ in $\mathrm{H}_{2} \mathrm{O}(2.9 \mathrm{~mL})$ was added to the combined aqueous extract. The solution was extracted thrice with $\mathrm{CH}_{2} \mathrm{Cl}_{2}(3 \times$ $15 \mathrm{~mL}$ ), and the solvent was removed under vacuum to give triethyleneglycol monooxy(trisdimethylamino)phosphonium hexafluorophosphate as an off-white powder $(1.144 \mathrm{~g}, 53 \%$ yield). Spectral data: ${ }^{1} \mathrm{H}$ NMR $\left(\mathrm{CD}_{2} \mathrm{Cl}_{2}\right) \delta 4.3(\mathrm{~s}, 2 \mathrm{H}), 3.7(\mathrm{~m}, 8 \mathrm{H}), 2.8(\mathrm{t}, 9 \mathrm{H}), 2.7(\mathrm{t}, 9 \mathrm{H})$.

\section{Triethyleneglycol Mono[1 $\mathrm{H}, 1 \mathrm{H}$-perfluorooctyl]ether $\left(\mathrm{R}_{\mathrm{f}}-\mathrm{OEG}\right)$}

The sodium salt of $1 \mathrm{H}, 1 \mathrm{H}$-perfluorononanol was produced by proton exchange of $1 \mathrm{H}, 1 \mathrm{H}$ perfluorononanol (510 mg, $10 \mathrm{mmol}$, Lancaster Synthesis) and sodium methoxide ( $81 \mathrm{mg}, 10$ $\mathrm{mmol})$ in methanol $(6 \mathrm{~mL})$ followed by solvent removal under vacuum. Triethyleneglycol monooxy (trisdimethylamino)phosphonium hexafluorophosphate $(0.43 \mathrm{~g}, 10 \mathrm{mmol})$ was added to a solution of sodium $1 \mathrm{H}, 1 \mathrm{H}$-perfluorononanolate $(0.51 \mathrm{~g}, 12 \mathrm{mmol})$ in dioxane $(10 \mathrm{~mL})$ under $\mathrm{N}_{2}$. The reaction was heated to $60^{\circ} \mathrm{C}$ for $27 \mathrm{~h}$. The reaction mixture was extracted with diethyl ether $(30 \mathrm{~mL})$, washed with dilute aqueous $\mathrm{HCl}(10 \mathrm{~mL})$, and dried with $\mathrm{MgSO}_{4}$. Solvent was removed under vacuum to give $0.294 \mathrm{~g}$ of crude product. Purification by chromatography on silica gel using ethyl acetate as the eluent gave triethyleneglycol mono[ $[1 \mathrm{H}$, $1 \mathrm{H}$-perfluorooctyl] ether $\left(R_{f}=0.32\right)$ as a colorless oil $\left(0.161 \mathrm{~g}, 30 \%\right.$ yield). Spectral data: ${ }^{1} \mathrm{H}$ NMR $\left(\mathrm{CDCl}_{3}\right) \delta 4.1(\mathrm{~d}, 2 \mathrm{H}), 3.7(\mathrm{~m}, 12 \mathrm{H}), 2.2(\mathrm{~s}, 1 \mathrm{H}) ;{ }^{13} \mathrm{C} \mathrm{NMR}\left(\mathrm{CDCl}_{3}\right) \delta 72.35,72.28$, $70.70,70.48,70.27,68.20(\mathrm{t}, J=0.2 \mathrm{~Hz}), 61.67$. Electrospray mass spectrometry showed a single peak at $582.9 \mathrm{~m} / \mathrm{z}$.

\section{Drop Tensiometry Setup}

Experimental Setup-A tensiometry setup using a 10x precision telecentric zoom lens (Edmund Optics, Barrington, NJ) coupled to a Spot Firewire CCD camera (Insight, Sterling Heights, MI) to visualize droplets hanging from disposable droplet extrusion tips was assembled on a sturdy, vibration-isolated benchtop. The distortion due to spherical aberration of the lens was measured to be $<0.3 \%$ across the field of view. Extrusion tips were assembled by using quick-set epoxy to glue 30-gauge Teflon tubing into a 1-10-L disposable pipet tip. Pipet tips were oxidized in a Plasma Prep II plasma cleaner (SPI Supplies, West Chester, PA) for $3 \mathrm{~min}$ to render them hydrophilic. Fluorous surfactant solution was loaded into a 50-L Hamilton Gastight (Reno, NV) syringe, and the Teflon tube-pipet tip assembly was flushed several times with the fluorous solution. The syringe was attached to a PHD 2000 Infusion syringe pump (Harvard Apparatus, Holliston, MA). A polystyrene cuvette containing a buffer solution and a circular stir bar rotating at 100-300 rpm was placed on a stir plate in front of the lens. The extrusion tip was inserted into the cuvette and held in place by a clamp. The camera-lens assembly was focused on the tip. A 1-2-L droplet of fluorous solution was extruded rapidly at a flow rate of $160 \mathrm{~L} \mathrm{~min}^{-1}$. Images were obtained at drop formation and at 10-s intervals thereafter. The cuvette containing the buffer was replaced with a cuvette containing $10 \mathrm{~g} \mathrm{~mL}^{-1}$ protein solution and a circular stir bar, a fresh fluorous droplet was 
extruded, and a second series of images was obtained. Long-term adsorption experiments using $1 \mathrm{mg} \mathrm{mL}^{-1}$ fibrinogen solution at $\mathrm{R}_{\mathrm{f}}$-OEG interfaces were performed with a tip assembly incorporating a 200-mm-i.d. silica capillary instead of a Teflon tube to eliminate the evaporation of fluorous solution through tubing over several hours. Long-term experiments were not stirred in order to not disturb the fluorous droplet hanging from the tip assembly.

Data Analysis-Metamorph version 6.1r3 (Universal Imaging Corp, Downington, PA) was used to analyze drop profiles. A Microsoft Excel spreadsheet was programmed to fit droplet profiles to a numerical solution of the Young-Laplace equation. ${ }^{78}$ This program yielded surface tension data for each picture in each time series. Images were analyzed until an equilibrium surface tension was obtained. Igor Pro (WaveMetrics, Inc., Lake Oswego, OR) was used to plot surface tension data and extract rate constants of adsorption.

\section{Microfluidic setup}

Device Fabrication-Poly(dimethylsiloxane) (PDMS, Sylgard Brand 184 Silicone Elastomer Kit) was obtained from Dow Corning (Midland, MI). To detect lower fluorescence intensity, black PDMS devices were fabricated by mixing 1:40 (w/w) of Regal 660R carbon black (Cabot Corporation, Boston, MA) to PDMS (10:1 w/w ratio of elastomer to curing agent). Using rapid prototyping in PDMS, ${ }^{79}$ microchannels were fabricated with rectangular cross sections and sealed to glass cover slips (no. 1) using a Plasma Prep II plasma cleaner.

Microchannels were rendered hydrophobic and fluorophilic using the following protocol: bake at $120^{\circ} \mathrm{C}$ for $1 \mathrm{~h}$, use dry $\mathrm{N}_{2}$ at $100 \mathrm{mmHg}$ to flow (tridecafluoro-1,1,2,2,-tetrahydrooctyl)-1trichlorosilane (United Chemical Technologies, Inc., Bristol, PA) vapor through the device for $1 \mathrm{~h}$, fill the device with a mixture of 10:1 (v/v) of FC-3283 to $\mathrm{R}_{\mathrm{f}}-\mathrm{CH}_{2} \mathrm{CH}_{2} \mathrm{OH}$ and then bake in $60^{\circ} \mathrm{C}$ for $1 \mathrm{~h}$.

Microfluidic Experiments-Aqueous and fluorous liquids were filled into 1700 series Gastight syringes (Hamilton Company), which were connected to the microfluidic device by 30-gauge Teflon tubing (Weico Wire \& Cable, Edgewood, NY). Syringes and the Teflon tubing were blocked with $1 \%(\mathrm{w} / \mathrm{v})$ BSA solution in PBS. Syringes were driven by PHD 2000 Infusion syringe pumps (Harvard Apparatus, Holliston, MA). Fluorescence and brightfield microphotographs were acquired through the cover slip side of the microfluidic device using a Leica DM IRE2 microscope with a cooled CCD camera ORCA ERG 1394 (12-bit, $1344 \times$ 1024 resolution) (Hamamatsu Photonics, K. K., Hamamatsu City, Japan). Lighting was provided by a 130-W Xe light source (Optiquip, Highland Mills, NY). MetaMorph Imaging System version 6.1r3 (Universal Imaging Corp) was used to collect and to analyze images. Images were integrated for $0.5-5 \mathrm{~s}$.

\section{Enzyme Kinetics Experiments}

First, steady-state kinetic parameters $\left(k_{\mathrm{cat}} / K_{\mathrm{M}}\right)$ for alkaline phosphatase and ribonuclease A were obtained by standard fluorimeter kinetic experiments. These kinetic parameters were used to determine the expected kinetic curve for fully active enzyme. Second, enzyme kinetics was measured in the plug-based microfluidic device. Third, the kinetic data from microfluidic experiments were compared to the expected kinetic curve. Enzyme activity was considered to be preserved and protein adsorption absent only if the microfluidic kinetic data overlaid with the expected kinetic curve determined from the fluorimeter kinetic experiments. Fourth, numerical simulations were performed using Igor Pro for enzyme kinetics that showed evidence of protein adsorption. These simulations predicted how the enzyme kinetics within the aqueous plug should be affected by enzyme adsorption at the aqueous-fluorous interface.

Fluorimeter Kinetic Experiments-The activity of the enzyme was determined by reacting the enzyme with a corresponding fluorogenic substrate and using a fluorimeter to 
measure the increasing fluorescence intensity over the reaction time. Kinetic measurements for AP with fluorescein diphosphate (FDP) as the substrate were performed using a fluorimeter (Fluoromax-3 Fluorescence Spectroscopy System, Jovin Yvon Horiba, Tokyo, Japan); steadystate kinetic parameters were obtained from the fluorimeter data, where $k_{\mathrm{cat}} / K_{\mathrm{M}}=0.75 \mathrm{M}^{-1}$ $\mathrm{s}^{-1}$. With these $k_{\text {cat }} / K_{\mathrm{M}}$ values, the expected kinetic curve for fully active AP enzyme was determined. Kinetics was also measured for RNase A with RNase Alert as the substrate, where $k_{\text {cat }} / K_{\mathrm{M}}=31.9 \mathrm{M}^{-1} \mathrm{~s}^{-1}$. The expected kinetic curve for fully active RNase A enzyme was also determined. Alkaline phosphatase concentrations of $0.05,0.1$, and $0.2 \mathrm{M}$ with FDP of $2.0 \mathrm{M}$ were used both for fluorimeter and microfluidic experiments.

Microfluidic Kinetic Experiments-For AP kinetics, the three stock solutions in the aqueous syringes were $0.3 \mathrm{M}$ AP in DEA buffer, DEA buffer, and $6 \mathrm{M}$ FDP in DEA buffer. For RNase A kinetics, the three stock solutions in the aqueous syringes were $60 \mathrm{nM}$ RNase A in TE buffer, TE buffer, and 2.5 M RNaseAlert in TE buffer. Microfluidic kinetic experiments were measured for AP with each of the three surfactants, as well as for RNase A with each of the three surfactants. These experiments were performed as described previously ${ }^{2}$ with the following modifications. Fluorescence images of the microchannels were obtained and analyzed using MetaMorph version 6.1r3. Images were acquired at nine specific distances $\left(d_{1}-d_{9}\right)$ along the microchannel. For $d_{1}$ to $d_{3}, 3$ images were acquired at each specific distance, and each image was acquired with an exposure time of $5 \mathrm{~s}$ to measure low levels of intensity. For $d_{4}-d_{6}, 5$ images were acquired at each specific distance, and each image was acquired with an exposure time of $3 \mathrm{~s}$. For $d_{7}-d_{9}, 30$ images were acquired at each specific distance, and each image was acquired with an exposure time of $0.5 \mathrm{~s}$ so that high levels of intensity would not saturate the CCD chip. At each specific microchannel distance, those images were arithmetically added to construct a new image that had a total integration time of $15 \mathrm{~s}$. Using this new image, integrated intensity measurements were made at each specific distance, where this distance was converted into time by using the total flow velocity. Integrated intensity measurements $\left(I_{t}\right)$ were converted into the time-dependent product concentration $[P]_{t}$ using $[P]_{t}=[S]_{0} \times\left(I_{t} / I_{\max }\right)$, where $[S]_{0}$ is the initial substrate concentration and $I_{\max }$ is the measured maximum intensity for fully reacted substrate at that initial concentration. Initial intensity $\left(I_{0}\right)$ of the product at $t=0$ was minimal $\left(I_{0}=0\right)$. Constant values for $I_{\max }$ were used for each of the two fluorogenic substrates (FDP and RNaseAlert).

\section{RESULTS AND DISCUSSION}

Experiments involving poly(ethylene glycol) in other systems suggest that adsorption of proteins at the aqueous-fluorous interface can be controlled by using fluorinated solutions of perfluorinated alkane surfactants capped with polar functional groups (Figure 1). These surfactants arrange themselves at the aqueous-fluorous interface with the polar functional group in the aqueous phase and the fluorinated alkane tail in the fluorous phase. ${ }^{80}$ They are soluble in fluorinated oils, but insoluble in water. To form plugs reliably, this microfluidic system requires some fluorous-soluble surfactant to lower the surface tension at the aqueousfluorous interface. To avoid the adhesion of aqueous droplets to PDMS, the surface tension at the aqueous-fluorous interface must be lower than the surface tension at the aqueous-PDMS interface at the channel wall. ${ }^{17}$ Surface tension should not be lowered too far. The capillary number $\mathrm{Ca}$ of the flow must be kept sufficiently low to ensure plug formation, 81 where $\mathrm{Ca}=$ $U / \gamma$, where $\left[\mathrm{kg} \mathrm{m}^{-1} \mathrm{~s}^{-1}\right]$ is viscosity, $U\left[\mathrm{~m} \mathrm{~s}^{-1}\right]$ is the total flow velocity, and $\gamma\left[\mathrm{N} \mathrm{m}^{-1}\right]$ is the interfacial surface tension. It is desirable to use high total flow velocities to perform rapid kinetic assays. If the flow rate is high, then surface tension must also be sufficiently high, so that $\mathrm{Ca}$ is kept at a sufficiently low value. Higher values of $\mathrm{Ca}>0.1$ result in laminar, continuous flow of immiscible fluids instead of discrete plug formation. ${ }^{81}$ We have found that an equilibrium surface tension at the fluorous-aqueous interface of $10-20 \mathrm{mN} \mathrm{m}^{-1}$ is optimal for 
plug formation of aqueous protein and buffer solutions with viscosities close to that of water. All surfactants used in this study gave acceptable plug formation.

We hypothesized that a neutral oligoethylene glycol (OEG) functional group presented by a fluorous-phase surfactant would resist protein adsorption, $36,37,44-50,55-65$ resulting in plugs with no adsorption and full enzymatic activity (if the protein is an enzyme). Perfluorinatedtail, oligoethylene glycol derivatized molecules $\left(\mathrm{R}_{\mathrm{f}}-\mathrm{OEG}\right)$ were selected as a neutral and hypothetically biocompatible surfactants. We hypothesized that a charged surfactant with a carboxylic acid functional group would cause some proteins to adsorb to the aqueous-fluorous interface, causing a consequent loss of enzymatic activity. We used perfluorotetradecanoic acid $\left(\mathrm{R}_{\mathrm{f}}-\mathrm{COOH}\right)$ to test this hypothesis. We have previously used $1 \mathrm{H}, 1 \mathrm{H}, 2 \mathrm{H}, 2 \mathrm{H}$-perfluoro-1octanol $\left(\mathrm{R}_{\mathrm{f}}-\mathrm{CH}_{2} \mathrm{CH}_{2} \mathrm{OH}\right)$ to successfully perform enzymatic measurements. ${ }^{2}$ Here, we have included $\mathrm{R}_{\mathrm{f}}-\mathrm{CH}_{2} \mathrm{CH}_{2} \mathrm{OH}$ to obtain complete adsorption analysis of this surfactant and to compare it to $\mathrm{R}_{\mathrm{f}}-\mathrm{OEG}$ and $\mathrm{R}_{\mathrm{f}}-\mathrm{COOH}$.

\section{Simple Theory of Adsorption}

To obtain information about the amount of protein adsorbed at the interface from interfacial surface tension measurements, we assumed that Langmuir kinetics (eq 1) adequately described adsorption at sufficiently early times. ${ }^{82}$ As a surface-active solute adsorbs to an interface, it covers a certain area on the interface. This area increases with time, resulting in a surface coverage of $\Gamma(t)$ [moles $\left.\mathrm{m}^{-2}\right]$ at time $t ; \Gamma_{\max }\left[\right.$ moles $\left.\mathrm{m}^{-2}\right]$ is the surface coverage when the interface becomes saturated and no more solute can adsorb. In the Langmuir model, the rate of adsorption of a solute with bulk concentration $C$ to a surface over time is expressed as

$$
\mathrm{d} \theta \mid \mathrm{d} t=k_{\mathrm{a}} C\left(1-\theta_{t}\right)
$$

where $\theta_{t}$ is the fractional, unitless surface coverage at time $t\left(\theta_{t}=\Gamma(t) / \Gamma_{\max }\right)$. The rate constant of adsorption is $k_{\mathrm{a}}\left[\mathrm{m}^{3} \mathrm{~mol}^{-1} \mathrm{~s}^{-1}\right]$, and $C\left[\mathrm{~mol} \mathrm{~m}^{-3}\right]$ is the bulk concentration of the solute. This treatment assumes that bulk concentration does not decrease over time. The integrated form of this equation is

$$
\ln \left(1-\theta_{t}\right)=-k_{a} C t
$$

Equations 1 and 2 assume that the protein adsorption to the surface is irreversible. Equation 3 is an equation of state that relates the surface pressure $\Pi(t)$ at time $t$ to $\theta_{t} .{ }^{83}$ The surface pressure $\Pi\left[\mathrm{mN} \mathrm{m}^{-1}\right]$ is defined as the difference between the surface tension of a "pure" interface, with no surfactant added, and the surface tension of the "test" interface, with surfactant added. ${ }^{83}$ Equation 3 assumes that the surfactant concentration is low and that the interface is not completely saturated. By making the approximation $\ln \left(1-\theta_{t}\right)=\theta_{t}$ (which is true at low values of $\theta_{t}$ ) in eq 2 and then substituting eq 2 into eq 3 , we obtain eq 4 , which relates $\Pi(t)$ to time $t$, where $R$ is the universal gas constant $\left[8.3145 \mathrm{~J} \mathrm{~mol}^{-1} \mathrm{~K}^{-1}\right]$ and $T$ is the temperature $[\mathrm{K}]$. Equation 4 is valid only at early times when surface coverage is low, because this equation assumes that surface saturation does not occur.

$$
\begin{gathered}
\Pi(t)=-R T \Gamma_{\text {max }} \theta_{t} \\
\Pi(t)=\left(k_{\mathrm{a}} C R T \Gamma_{\max }\right) \times t
\end{gathered}
$$

We used eq 4 to obtain the rate constant of protein adsorption $k_{\mathrm{a}}$ from dynamic surface tension measurements in cases where adsorption was observed. This equation is an oversimplification when applied to adsorption of proteins, as discussed below. 


\section{Adsorption Measurements Within Droplets Using Drop Tensiometry}

We measured the adsorption of proteins and surfactants through drop tensiometry. Drop tensiometry has been used previously to measure the rate of organic interfacial reactions 84 and the rate of protein adsorption to aqueous-hydrocarbon ${ }^{42}$ and aqueous-air interfaces. ${ }^{85} \mathrm{In}$ tensiometry, a pendant liquid droplet is formed inside an immiscible fluid, and the surface tension of the droplet is measured over time. ${ }^{78,86,87}$ Decreasing surface tension elongates the profile of a pendant droplet from spherical (Figure 2a) to teardrop (Figure 2b) geometry, as the surface's ability to counteract gravity diminishes. Surface tension can be quantified by fitting the droplet profile to the Young-Laplace equation. ${ }^{83}$ Interfacial surface tension decreases as adsorption increases; therefore, surface tension decreases with increasing surface concentration of surfactant and protein.

Bovine serum albumin and human serum fibrinogen are proteins that are known to adsorb to a wide variety of surfaces and are often used as test cases in studies of protein adsorption. $61-$ $63,65,67,68,88-96$ We used these proteins to test the hypothesis that an interface presenting the $\mathrm{R}_{\mathrm{f}}$-OEG surfactant would resist nonspecific protein adsorption. For this discussion, we use the shorthand notation (AQUEOUS)/(FLUOROUS) to refer to aqueous-fluorous interfaces. Items to the left of the/symbol are in the aqueous phase, and items to the right of the/symbol are in the fluorous phase, where "" represents the interface between two immiscible solutions. We further separate the aqueous phase into (BUFFER + PROTEIN) and the fluorous phase into (SURFACTANT + FC), where FC stands for the fluorocarbon oil. Therefore, (buffer + fibrinogen $) /\left(\mathrm{R}_{\mathrm{f}}-\mathrm{OEG}+\mathrm{FC}\right)$ refers to a droplet of fluorous $\mathrm{R}_{\mathrm{f}}-\mathrm{OEG}$ solution formed in an aqueous solution of fibrinogen. We measured the adsorption of BSA to FC without (Figure $3 a$ ) and with (Figure $3 b$ ) $\mathrm{R}_{\mathrm{f}}$-OEG surfactant. Since the (buffer)/(FC) control has no species that can adsorb to the aqueous-fluorous interface, the variation of its surface tension over time serves as a measure of the experimental error of the tensiometry apparatus. The experiment with the (buffer + BSA)/(FC) test droplet (Figure 3a, closed symbols) showed a lower dynamic surface tension than the (buffer)/(FC) control droplet, indicating BSA adsorption to the aqueous-FC interface (Figure 3a). The dynamic surface tension of the (buffer $+\mathrm{BSA}) /\left(\mathrm{R}_{\mathrm{f}}\right.$ $\mathrm{OEG}+\mathrm{FC}$ ) test droplet (Figure 3b, closed symbols) Matched the dynamic surface tension of the (buffer)/( $\mathrm{R}_{\mathrm{f}}-\mathrm{OEG}+\mathrm{FC}$ ) control droplet (Figure $3 \mathrm{~b}$, open symbols), indicating that BSA did not adsorb to the interface that presented the $R_{f}$-OEG surfactant. Similarly, we found that fibrinogen adsorbed to interfaces presenting either of the $\mathrm{R}_{\mathrm{f}}-\mathrm{COOH}$ (Figure $4 \mathrm{a}$ ) or $\mathrm{R}_{\mathrm{f}}$ $\mathrm{CH}_{2} \mathrm{CH}_{2} \mathrm{OH}$ (Figure $4 \mathrm{~b}$ ) surfactants, but not the $\mathrm{R}_{\mathrm{f}}$-OEG surfactant (Figure $4 \mathrm{c}$, d). Adsorption of the protein caused an additional decrease in surface tension beyond the surface tension of the surfactant-only experiment. We also measured the adsorption of fibrinogen to a pure fluorocarbon interface (buffer + fibrinogen)/(FC) (Supporting Information) and observed adsorption similar to that of the (buffer + BSA)/(FC) experiment.

In both drop tensiometry and microfluidic devices, surfactant and protein are adsorbing simultaneously at the aqueous-fluorous interface. For the present study, we are interested in the rate of adsorption of the protein, not of the surfactant. Therefore, control experiments were performed with buffer solutions as the aqueous phase, and test experiments were performed with protein-in-buffer solutions. For the dilute surfactant $\mathrm{R}_{\mathrm{f}}-\mathrm{COOH}$, surfactant and protein adsorbed on a similar time scale. For the more concentrated surfactant $\mathrm{R}_{\mathrm{f}}-\mathrm{CH}_{2} \mathrm{CH}_{2} \mathrm{OH}$, the surfactant adsorbed significantly faster than the protein. Drop tensiometry of protein adsorption to aqueous-fluid interfaces often show an "induction time," during which adsorption is limited by protein diffusion to the interface. ${ }^{97}$ These periods are characterized by a slow decrease of surface tension over time, followed by a rapid adsorption period during which surface tension declines quickly. This induction period shortens as protein concentration is increased. The fibrinogen experiments with $\mathrm{R}_{\mathrm{f}}-\mathrm{COOH}$ (Figure $4 \mathrm{a}$ ) and $\mathrm{R}_{\mathrm{f}}-\mathrm{CH}_{2}-\mathrm{CH}_{2} \mathrm{OH}$ (Figure $4 \mathrm{~b}$ ) that displayed adsorption did not show induction periods; the surface tension of the interface fell 
quickly after drop formation. To establish that the $\mathrm{R}_{\mathrm{f}}$-OEG surfactant-presenting interface did not have an induction time longer than the duration of the experiments, we performed a (buffer + fibrinogen $) /\left(\mathrm{R}_{\mathrm{f}}-\mathrm{OEG}+\mathrm{FC}\right)$ experiment using a very concentrated $1 \mathrm{mg} \mathrm{mL}^{-1}$ fibrinogen solution (Figure $4 \mathrm{~d}$ ) over a long period of time, $10000 \mathrm{~s}$. This experiment was successfully performed using both the synthesized and extracted $R_{f}-O E G$. This experiment showed no difference in surface tension between the (buffer)/( $\mathrm{R}_{\mathrm{f}}-\mathrm{OEG}+\mathrm{FC}$ ) control (Figure $4 \mathrm{~d}$, open symbols) and the (buffer + fibrinogen)/( $\mathrm{R}_{\mathrm{f}}-\mathrm{OEG}+\mathrm{FC}$ ) test (Figure $4 \mathrm{~d}$, closed symbols), indicating that there is no induction period for the interface that presented the $\mathrm{R}_{\mathrm{f}}-\mathrm{OEG}$ surfactant. When fibrinogen adsorbed to interfaces presenting $\mathrm{R}_{\mathrm{f}}-\mathrm{COOH}$ and $\mathrm{R}_{\mathrm{f}}-\mathrm{CH}_{2} \mathrm{CH}_{2} \mathrm{OH}$ surfactants, the surface tension decreased to $11-12 \mathrm{mN} \mathrm{m}^{-1}$. At an interface presenting the $\mathrm{R}_{\mathrm{f}}$-OEG surfactant, the surface tension stayed at a higher value of $\sim 17 \mathrm{mN} \mathrm{m}^{-1}$, confirming that no adsorption of fibrinogen occurred.

\section{Adsorption of Enzymes}

Having demonstrated that "sticky" proteins, such as BSA and fibrinogen, did not adsorb to interfaces that presented the $\mathrm{R}_{\mathrm{f}}$-OEG surfactant, we investigated the adsorption of enzymes that could be analyzed by both drop tensiometry and enzyme kinetic assays. By measuring enzyme adsorption at aqueous-fluorous interfaces in microliter-sized droplets, we can make predictions about adsorption in nanoliter-sized plugs. Validating these predictions by measuring enzyme kinetics in plugs formed inside a microfluidic device using the fluorous surfactant solutions would quantitatively demonstrate the compatibility of plug-based microfluidics with enzymes. We chose ribonuclease $\mathrm{A}^{98}$ (RNase A) and alkaline phosphatase $^{99}$ (AP) as test enzymes. RNase A is positively charged, and AP is negatively charged in optimal reaction conditions. Both enzymes have well-characterized kinetics that can be used as standards.

Drop tensiometry indicated that RNase A adsorbed to interfaces presenting $\mathrm{R}_{\mathrm{f}}-\mathrm{COOH}$ (Figure 5a) but did not adsorb to interfaces presenting either $\mathrm{R}_{\mathrm{f}}-\mathrm{CH}_{2} \mathrm{CH}_{2} \mathrm{OH}$ (Figure 5b) or $\mathrm{R}_{\mathrm{f}}-\mathrm{OEG}$ (Figure 5c). We measured the adsorption of AP to interfaces that presented one of the three surfactants, $\mathrm{R}_{\mathrm{f}}-\mathrm{COOH}, \mathrm{R}_{\mathrm{f}}-\mathrm{CH}_{2} \mathrm{CH}_{2} \mathrm{OH}$, and $\mathrm{R}_{\mathrm{f}}-\mathrm{OEG}$ (Supporting Information). AP was not found to adsorb significantly to interfaces presenting any of the three surfactants. The use of eq 4 to interpret surface tension data is an oversimplification when applied to protein adsorption. ${ }^{42,93}$ Equation 4 assumes ideal behavior, where the protein is a sphere in a single contact with the interface. This assumption is poor for larger proteins, which presumably adsorb to the interface with multiple contact points, especially as they denature. Therefore, this assumption underestimates the number of contact points, $\Gamma^{\prime}{ }_{\max }$, and thus, overestimates the rate constant for adsorption. In addition, protein solutions deviate greatly from ideality, and electrostatic interactions are known to influence decrease of surface tension. ${ }^{41}$

To obtain the rate constant of adsorption of enzymes to nonbiocompatible interfaces, we extrapolated the surface pressure $\Pi\left[\mathrm{mN} \mathrm{m}^{-1}\right]$ from surface tension data. Typically in surface studies, the surface pressure $\Pi$ is used to denote the difference between the pure interface (with no added surfactant) and the test interface (with surfactant). ${ }^{83}$ To differentiate between surfactant adsorption to the interface and protein adsorption to the interface, we define $\Pi[\mathrm{mN}$ $\left.\mathrm{m}^{-1}\right]$ as the difference between the surface tension of the (buffer)/(surfactant $+\mathrm{FC}$ ) control droplet and the surface tension of the (buffer + protein)/(surfactant + FC) test droplet. To measure $\Pi$ for RNase $A$ at the interface that presented the $\mathrm{R}_{\mathrm{f}}-\mathrm{COOH}$ surfactant, we fit the surface tension over time for both the control and test droplet to exponential curves (Figure 5 a, black curves). The test fit was subtracted from the control fit, producing a surface pressure graph (Figure 5d). We fit the linear expansion of the surface pressure fit to eq 4 and extracted the rate constant of adsorption. Therefore, using these experimental measurements, we can quantify the rate of adsorption at the interface of droplets. Analysis of RNase A surface pressure 
data using eq 4 gave a rate constant of adsorption of $2.0 \times 10^{-2} \mathrm{~mL} \mathrm{~g}^{-1} \mathrm{~s}^{-1}$ at the interface that presented the $\mathrm{R}_{\mathrm{f}}-\mathrm{COOH}$ surfactant. Similarly, the rate constant of adsorption for fibrinogen at an interface presenting the $\mathrm{R}_{\mathrm{f}}-\mathrm{COOH}$ surfactant was $5.1 \times 10^{-2} \mathrm{~mL} \mathrm{~g}^{-1} \mathrm{~s}^{-1}$. Siegel et al. measured the rate constant of adsorption of $14 \mathrm{~g} \mathrm{~mL}^{-1}$ fibrinogen to a methyl-terminated alkanethiol self-assembled monolayer (SAM) as $3.66 \times 10^{-3} \mathrm{~mL} \mathrm{~g}^{-1} \mathrm{~s}^{-1}$ using acoustic plate mode sensing. ${ }^{100}$ The higher value of the rate constant obtained from tensiometry could be either due to faster adsorption of fibrinogen to a charged interface or, as discussed above, due to the assumptions-incorrect for fibrinogen-of eq 4.

The rate of protein adsorption to an interface may be limited by transport, in which the protein diffuses toward the interface, or by the subsequent period of adsorption, in which the protein physically adsorbs to the interface. Some theoretical models of protein adsorption assume diffusion to be the dominant process. ${ }^{72}$ To establish that the rate being measured by drop tensiometry was the rate of protein adsorbing to the interface rather than the rate of protein diffusing to the interface, we performed adsorption experiments in stirred and unstirred cuvettes for RNase A at the interface that presented the $\mathrm{R}_{\mathrm{f}}-\mathrm{COOH}$ surfactant. Stirring accelerates convective transport. If transport, rather than adsorption, was the rate-limiting process, then the measured rate of adsorption would be increased for the stirred experiment. We found no difference between the rate of adsorption in stirred and unstirred experiments, indicating that protein diffusion was not the rate-limiting process in adsorption to these interfaces.

Denaturation of an adsorbed protein layer has also been demonstrated to decrease the surface tension of an interface. ${ }^{96}$ To test whether the quantity measured in tensiometry is adsorption rather than denaturation, we measured the adsorption of three concentrations of fibrinogen to an interface that presented the $\mathrm{R}_{\mathrm{f}}-\mathrm{COOH}$ surfactant. If denaturation, and not adsorption, was occurring, each concentration would display the same rate of surface tension decrease. If adsorption, and not denaturation, was occurring, high bulk concentration of fibrinogen would cause a faster decrease in surface tension over low bulk concentration. However, at sufficiently long time, each concentration would reach an identical equilibrium surface tension. The latter case was observed (Supporting Information). We are most interested in using tensiometry to find surfactants that proteins do not absorb to. Therefore, any adsorption that is observed with a surfactant, regardless whether the mechanism of surface tension decrease is adsorption, denaturation, or some combination of the two, can be used to evaluate this surfactant for microfluidic applications.

Making Predictions for Adsorption within Plugs-The rate constants for adsorption $k_{\mathrm{a}}$ obtained by tensiometry are very approximate due to the multiple assumptions used. We wished to understand if these rate constants would be useful for estimating the extent of protein adsorption in nanoliter plugs. In microliter droplets, the adsorption occurs in the excess of the protein and is limited by the area of the interface. In nanoliter plugs, due to a much higher surface-to-volume ratio, the adsorption occurs in the excess of the interface and is limited by the amount of the protein available. Adsorption will significantly reduce the concentration of the protein in plugs with dimensions smaller than approximately $\Gamma_{\max } / C_{0} \cdot{ }^{101}$ As the protein is adsorbing at the interface of a plug, by conservation of mass,

$$
c_{t}=c_{0}-(\mathrm{SA} / v) \Gamma(t)
$$

where $C_{t}\left[\mathrm{~mol} \mathrm{~m}^{-3}\right]$ is the time-dependent protein concentration in the plug at time $t, C_{0}[\mathrm{~mol}$ $\left.\mathrm{m}^{-3}\right]$ is the initial protein concentration in the plug, SA $\left[\mathrm{m}^{2}\right]$ is the surface area of the plug, $V\left[\mathrm{~m}^{3}\right]$ is the volume of the plug, and $\Gamma(t)\left[\mathrm{mol} \mathrm{m}^{-2}\right]$ is the surface coverage of the protein at time $t$. Due to the high surface area-to-volume ratio for plugs, surface coverage is always small. Therefore, $k_{\mathrm{a}}$ obtained from the initial rate of adsorption should adequately describe the 
process. The rate of adsorption that accounts for time-dependent protein concentration $C_{t}$ can be expressed as

$$
\mathrm{d} \theta_{\mathrm{t}} / C_{t}=k_{\mathrm{a}} \mathrm{d} t
$$

By using $\theta_{t}=\Gamma(t) / \Gamma_{\max }$ and eq 5 to express $\theta_{t}$ in terms of $C_{t}$, the integrated form of eq 6 is

$$
\begin{aligned}
& \operatorname{In}\left(C_{t} \mid C_{0}\right)=-k_{\mathrm{a}} t(\mathrm{SA} / V) \Gamma_{\max } \\
& C_{t}=C_{0} \exp \left(-k_{\mathrm{a}} t(\mathrm{SA} / V) \Gamma_{\max }\right)
\end{aligned}
$$

To relate adsorption in droplets and in plugs, we calculated $C_{t}$ as a function of time using eq 7. To predict how adsorption in plugs would affect enzyme kinetics, we used $C_{t}$ to numerically solve for product formation according to Michaelis-Menten kinetics.

\section{Testing Predictions for Adsorption in Plugs}

\section{Qualitatively Testing Predictions of Adsorption with Fluorescently Labeled}

Proteins in Plugs-We used fluorescence microscopy to detect adsorption 102 of fluorescently labeled fibrinogen at the liquid-liquid interface of plugs. Adsorption was indicated by bright fluorescence at the edge of the plug, whereas uniform intensity of fluorescence across the plug indicated lack of adsorption. Adsorption was observed at the interface for the (buffer + AlexaFluor-fibrinogen) $/\left(\mathrm{R}_{\mathrm{f}}-\mathrm{CH}_{2}-\mathrm{CH}_{2} \mathrm{OH}+\mathrm{FC}\right.$ ) plug (Figure 6a) but not the (buffer + AlexaFluor-fibrinogen) $/\left(\mathrm{R}_{\mathrm{f}}-\mathrm{OEG}+\mathrm{FC}\right.$ ) plug (Figure 6b), in agreement with the predictions made with tensiometry.

\section{Quantitatively Testing Predictions of Adsorption by Measuring Enzyme Kinetics} in Plugs-Tensiometry is a useful measure of protein adsorption, but it is possible that it would not detect adsorption in certain cases (for example, if the equilibrium surface tensions of the control and test experiments accidentally coincide, or if partial adsorption occurs that does not cause a measurable decrease in surface tension). Enzyme kinetics, a complementary method of detecting adsorption, was used to exclude these possibilities. Enzyme kinetics was measured in plugs in PDMS microfluidic devices. ${ }^{2}$ The activity of the enzyme was detected by measuring the increasing fluorescence of the fluorogenic substrate over time. Clear PDMS normally used to perform these experiments may transmit, scatter or reflect light, obstructing fluorescence measurements. To detect the changes in fluorescence intensity with higher sensitivity, black PDMS microfluidic devices were fabricated by suspending charcoal in PDMS prior to curing. Fluorescence microphotographs were obtained at specific distances along the microchannel network (Figure 7a, left), and intensity profiles were determined for these microphotographs (Figure 7a, right). By measuring the integrated intensity of these microphotographs at each distance, the activity of the enzyme was obtained as a function of time (Figure 7b-e).

\footnotetext{
Using Kinetics in Plugs To Test the Adsorption Rate Constant Obtained from Tensiometry: Enzyme Kinetics with $\mathbf{R}_{\mathbf{f}}-\mathbf{C O O H}$ Tensiometry experiments predicted that AP would not adsorb to the interface that presented the $\mathrm{R}_{\mathrm{f}}-\mathrm{COOH}$ surfactant. Kinetics was measured for (buffer $+\mathrm{AP}) /\left(\mathrm{R}_{\mathrm{f}}-\mathrm{COOH}+\mathrm{FC}\right.$ ) plugs in channels of two cross-sectional dimensions $w \times w$ (Figure 7b,c; red circles). For $w=50 \mathrm{~m}$, the measured AP kinetics in plugs (Figure $7 \mathrm{~b}$, red circles) showed slight deviation from the expected curve from fluorimetry (Figure 7b, black solid curve). For $w=150 \mathrm{~m}$, the kinetic measurements for $\mathrm{AP}$ with $\mathrm{R}_{\mathrm{f}}-\mathrm{COOH}$ (Figure 7c, red circles) was in adequate agreement with the expected kinetic curve for fully active AP (Figure 7c, black solid curve). In addition, Selwyn's test was performed to show that significant inactivation of AP did not occur in (buffer $+\mathrm{AP}) /\left(\mathrm{R}_{\mathrm{f}}-\mathrm{COOH}+\mathrm{FC}\right)$ plugs

(Supporting Information).
} 
Tensiometry predicted that RNase A would adsorb to an interface presenting the $\mathrm{R}_{\mathrm{f}}-\mathrm{COOH}$ surfactant. To test this prediction, enzyme kinetics of RNase A was measured using plugs formed in microchannels with $w=50 \mathrm{~m}$. To understand the effect that surface adsorption had on time-dependent enzyme concentration within the plug $\left(C_{t}\right)$, eq 7 was solved to obtain $C_{t}$, then this $C_{t}$ was used to predict the time-dependent product formation assuming MichaelisMenten kinetics. This numerical simulation was repeated, with the rate constant of adsorption $k_{\mathrm{a}}$ as the only adjustable parameter, until an adequate fit (Figure 7d, black dashed lines) to the experimental data (Figure 7d, red circles) was obtained. This fit gave $k_{\mathrm{a}}=1.4 \pm 0.1 \times 10^{-2} \mathrm{~mL}$ $\mathrm{g}^{-1} \mathrm{~s}^{-1}$, in surprisingly good agreement with $k_{\mathrm{a}}=2.0 \pm 0.3 \times 10^{-2} \mathrm{~mL} \mathrm{~g}^{-1} \mathrm{~s}^{-1}$ obtained from tensiometry. Efforts were made to fit the experimental data (Figure $7 \mathrm{~d}$, red circles) with Michaelis-Menten parameters; however, the curves obtained for any values of the MichaelisMenten parameters did not overlay with the experimental data. Therefore, when adsorption is present within plugs, Michaelis-Menten kinetic parameters cannot be determined.

Equation 7 predicts that increasing the volume-to-surface area ratio V/SA will increase the time scale required for adsorption. To test this prediction, enzyme kinetics of RNase A was measured using plugs formed in microchannels of cross-sectional dimension $150 \mathrm{~m} \times 150 \mathrm{~m}(w=150$ $\mathrm{m})$. Adsorption will decrease the concentration of the protein in plugs with dimensions on the scale of less than $\sim \Gamma_{\max } / \mathrm{C}_{0} .{ }^{101}$ This ratio is $\sim 1000 \mathrm{~m}$ for the RNase A experiments. For both $w=150 \mathrm{~m}$ and $w=50 \mathrm{~m}$ experiments, the length of the plug was three times the width of the plug, which was adjusted by controlling the relative flow rates of the aqueous and fluorous streams. 17,103 Under these conditions, the $V / S A$ ratio of the $w=150 \mathrm{~m}$ plug was three times larger than the $V / S A$ ratio of the $w=50 \mathrm{~m}$ plug. In agreement with the qualitative expectation, adsorption of the enzyme was less significant in the $w=150-\mathrm{m}$ plug and more product formed (Figure 7e, red circles). Numerical fit (Figure 7e, black dashed lines) to these data gave $k_{\mathrm{a}}=$ $0.9 \pm 0.1 \times 10^{-2} \mathrm{~mL} \mathrm{~g}^{-1} \mathrm{~s}^{-1}$. Despite numerous approximations, the rate constant of adsorption of enzymes obtained from drop tensiometry using microliter-sized droplets could be used to estimate the extent of adsorption in nanoliter-sized plugs. This agreement may be coincidental, or it could be due to the fact that eq 4 is much more applicable to RNase A than fibrinogen: RNase A is a smaller enzyme rigidified by disulfide bonds, and with lower tendency to denature at interfaces.

Enzyme kinetics with $\mathbf{R}_{\mathbf{f}}-\mathrm{CH}_{\mathbf{2}} \mathrm{CH}_{\mathbf{2}} \mathrm{OH}$-Tensiometry predicted that neither AP nor RNase A would adsorb to the interface that presented the $\mathrm{R}_{\mathrm{f}}-\mathrm{CH}_{2} \mathrm{CH}_{2} \mathrm{OH}$ surfactant. For $w=50 \mathrm{~m}$, the measured AP kinetics (Figure 7b, blue triangles) showed a slight deviation from the expected curve. For (buffer $+\mathrm{AP}) /\left(\mathrm{R}_{\mathrm{f}}-\mathrm{CH}_{2}-\mathrm{CH}_{2} \mathrm{OH}+\mathrm{FC}\right.$ ) plugs when $w=150 \mathrm{~m}$, the measured AP kinetics (Figure 7c, blue triangles) was indistinguishable from the expected kinetic curve. Similar results were obtained with Selwyn's test for (buffer $+\mathrm{AP}) /\left(\mathrm{R}_{\mathrm{f}}\right.$ $\mathrm{CH}_{2} \mathrm{CH}_{2} \mathrm{OH}+\mathrm{FC}$ ), where superimposable curves were obtained for $w=150 \mathrm{~m}$, but very slight deviations for $w=50 \mathrm{~m}$ (Supporting Information). These deviations may have resulted from the adsorption of AP within the plugs. We do not know if adsorption that may have caused these slight deviations is within the experimental error of the tensiometry measurements or if enzyme kinetics is more sensitive than tensiometry to changes in enzyme concentration. For (buffer + RNase $\mathrm{A}) /\left(\mathrm{R}_{\mathrm{f}}-\mathrm{CH}_{2} \mathrm{CH}_{2} \mathrm{OH}+\mathrm{FC}\right.$ ) plugs, experimental kinetic curves obtained for both values of $w=50 \mathrm{~m}$ (Figure 7d, blue triangles) and $w=150 \mathrm{~m}$ (Figure 7e, blue triangles) overlaid with the expected curves for fully active enzyme, in agreement with previous results.

Enzyme Kinetics with $\mathbf{R}_{\mathbf{f}}-\mathrm{OEG}$-With the $\mathrm{R}_{\mathrm{f}}$-OEG surfactant, tensiometry predicted that both AP and RNase A activity would be preserved in kinetic assays. For (buffer $+A P) /\left(R_{f}-\right.$ $\mathrm{OEG}+\mathrm{FC}$ ) plugs, the measured kinetic data overlaid well with the expected curve for both $w=50 \mathrm{~m}$ (Figure 7b, green squares) and $w=150 \mathrm{~m}$ (Figure 7c, green squares). Selwyn's test for (buffer $+\mathrm{AP}) /\left(\mathrm{R}_{\mathrm{f}}-\mathrm{OEG}+\mathrm{FC}\right)$ showed superimposable curves for both values of $w$ 
(Supporting Information). For (buffer + RNase A) $/\left(\mathrm{R}_{\mathrm{f}}-\mathrm{OEG}+\mathrm{FC}\right)$ plugs, the measured kinetic data overlaid well with the expected curve for both $w=50 \mathrm{~m}$ (Figure 7d, green squares) and $w=150 \mathrm{~m}$ (Figure 7e, green squares). Even slight deviations were not observed for either enzyme at both values of $w$ with $\mathrm{R}_{\mathrm{f}}$-OEG. Therefore, by using $\mathrm{R}_{\mathrm{f}}$-OEG, a biocompatible interface was achieved at the plug surface for these two enzymes, in agreement with the predictions made by tensiometry.

\section{CONCLUSION}

In conclusion, surface chemistry at the aqueous-fluorous interface of plug-based microfluidics was controlled using surfactants that are fluorous-soluble but water-insoluble. Through control of surface chemistry, nonspecific protein adsorption can be prevented. Adsorption can also be induced when necessary, and these cases need to be quantitatively characterized to understand how adsorption occurs. These results show that nonspecific adsorption of proteins can be induced by a charged carboxylic acid-capped surfactant $\mathrm{R}_{\mathrm{f}}-\mathrm{COOH}$. Perfluorooctanol $\left(\mathrm{R}_{\mathrm{f}}-\right.$ $\mathrm{CH}_{2} \mathrm{CH}_{2}-\mathrm{OH}$ ), a very convenient surfactant to use in plug-based microfluidics, resisted the adsorption of RNase A, but not of fibrinogen. Nonspecific adsorption was quantified with good agreement between two independent and complementary methods: drop tensiometry in microliter-sized droplets and enzyme kinetics in nanoliter-sized plugs. For future applications, such as protein crystallization and concentration or sorting of protein solutions, it may be desirable to cause adsorption within plugs. The methods to study and quantify adsorption were presented herein.

These methods show that nonspecific protein adsorption can be prevented by using oligoethylene-glycol capped surfactants. It was demonstrated that BSA and fibrinogen, proteins known to adsorb quickly and strongly to surfaces, did not adsorb to aqueous-fluorous interfaces that presented the $\mathrm{R}_{\mathrm{f}}$-OEG surfactant. These results strongly suggest that most other proteins would not adsorb to such interfaces, but they do not guarantee it. Synthesis of the $\mathrm{R}_{\mathrm{f}}$-OEG surfactant is straightforward, but the commercial availability of purified $\mathrm{R}_{\mathrm{f}}$-OEG surfactants would make the methods described in this paper accessible to a wider range of users. We found that $\mathrm{R}_{\mathrm{f}}$-OEG mixtures can be extracted from commercially available DuPont Zonyl FSO-100 surfactant (see Supporting Information for the experimental procedure and characterization). These mixtures are less desirable than the pure synthesized material for quantitative studies of adsorption due to some variability of composition from batch to batch. On the other hand, the mixture was as effective at preventing protein adsorption as the synthesized material. Concentrations of $\mathrm{R}_{\mathrm{f}}$-OEG from 0.16 to $0.72 \mathrm{mg} \mathrm{mL}^{-1}$ resisted the adsorption of $1 \mathrm{mg} \mathrm{mL}^{-1}$ fibrinogen for up to $3 \mathrm{~h}$. A fairly narrow range of $\mathrm{R}_{\mathrm{f}}$-OEG concentration was studied, since these concentrations were needed for optimal surface tension for adequate plug formation. Adsorption should be characterized for other applications that require different surfactant concentrations. The potential toxicity of fluorinated surfactants has to be kept in mind (see Experimental Section for details).

This approach to controlling interfacial properties in micro-fluidic devices is attractive because it requires no surface treatment of the walls of the device, as long as it is preferentially wetted by the fluorocarbon. In addition, different surface chemistries can be presented by simply changing the fluorous oil on the same device, without the need to introduce surfactants into the aqueous phase. These surfactants will be particularly useful not only in droplet-based microfluidics $14,16,22-26$ but also in electro-wetting $29,31-33,66,104$ applications or anywhere protein adsorption at the liquid-liquid interface is a problem. Using black PDMS (a suspension of charcoal in PDMS) to fabricate microfluidic devices simplified acquisition of fluorescent data in kinetic experiments. We are currently using the $\mathrm{R}_{\mathrm{f}}-\mathrm{OEG}$ surfactant to perform protein crystallization and enzyme kinetics. The use of the $\mathrm{R}_{\mathrm{f}}-\mathrm{OEG}$ surfactant would facilitate preparation, manipulation, and analysis of biomolecules and cells in plug-based 
microfluidic systems, since the surfactant self-assembles to give rise to an interface that is inert to nonspecific protein adsorption, with no need for additional fabrication or surface patterning of the walls of the microchannels.

\section{Acknowledgements}

This work was supported by the NIH (R01 EB001903), Dupont Young Professor Award (R.F.I.), the Burroughs Wellcome Fund Interfaces Fellowship No. 1001774 (L.S.R.) and the Predoctoral Training Grant (H.S.) of the NIH (GM 08720). At the University of Chicago, work was performed at the MRSEC microfluidic facility funded by the NSF. We thank Yelena Koldobskaya for help with numerical simulations.

\section{References}

1. Song H, Tice JD, Ismagilov RF. Angew Chem, Int Ed 2003;42:768-772.

2. Song H, Ismagilov RF. J Am Chem Soc 2003;125:14613-14619. [PubMed: 14624612]

3. Zheng B, Roach LS, Ismagilov RF. J Am Chem Soc 2003;125:11170-11171. [PubMed: 16220918]

4. Zheng B, Tice JD, Ismagilov RF. Adv Mater 2004;16:1365-1368.

5. Zheng B, Tice JD, Ismagilov RF. Anal Chem 2004;76:4977-4982. [PubMed: 15373431]

6. Zheng B, Tice JD, Roach LS, Ismagilov RF. Angew Chem, Int Ed 2004;43:2508-2511.

7. Kameoka J, Orth R, Ilic B, Czaplewski D, Wachs T, Craighead HG. Anal Chem 2002;74:5897-5901. [PubMed: 12463378]

8. Kamholz AE, Weigl BH, Finlayson BA, Yager P. Anal Chem 1999;71:5340-5347. [PubMed: 10596213]

9. Mao HB, Yang TL, Cremer PS. Anal Chem 2002;74:379-385. [PubMed: 11811412]

10. Tokeshi M, Minagawa T, Uchiyama K, Hibara A, Sato K, Hisamoto H, Kitamori T. Anal Chem 2002;74:1565-1571. [PubMed: 12033246]

11. Vilkner T, Janasek D, Manz A. Anal Chem 2004;76:3373-3385. [PubMed: 15193114]

12. Auroux PA, Iossifidis D, Reyes DR, Manz A. Anal Chem 2002;74:2637-2652. [PubMed: 12090654]

13. Auroux PA, Iossifidis D, Reyes DR, Manz A. Anal Chem 2002;74:2623-2636. [PubMed: 12090653]

14. Anna SL, Bontoux N, Stone HA. Appl Phys Lett 2003;82:364-366.

15. Hosokawa K, Fujii T, Endo I. Anal Chem 1999;71:4781-4785.

16. (a) Martin K, Henkel T, Baier V, Grodrian A, Schon T, Roth M, Kohler JM, Metze J. Lab Chip 2003;3:202-207. [PubMed: 15100775] (b) Henkel T, Bermig T, Kielpinski M, Grodrian A, Metze J, Kohler JM. Chem Eng J 2004;101:439-445. (c) Nisisako T, Torii T, Higuchi T. Lab Chip 2002;2:24-26. [PubMed: 15100856]

17. Tice JD, Song H, Lyon AD, Ismagilov RF. Langmuir 2003;19:9127-9133.

18. Yi GR, Thorsen T, Manoharan VN, Hwang MJ, Jeon SJ, Pine DJ, Quake SR, Yang SM. Adv Mater 2003;15:1300-1304.

19. Okushima S, Nisisako T, Torii T, Higuchi T. Langmuir 2004;20:9905-9908. [PubMed: 15518471]

20. (a) Khan SA, Gunther A, Schmidt MA, Jensen KF. Langmuir 2004;20:8604-8611. [PubMed: 15379481] (b) Gunther A, Khan SA, Thalmann M, Trachsel F, Jensen KF. Lab Chip 2004;4:278286. [PubMed: 15269792]

21. Gordillo JM, Cheng ZD, Ganan-Calvo AM, Marquez M, Weitz DA. Phys Fluids 2004;16:2828-2834.

22. Sugiura S, Nakajima M, Yamamoto K, Iwamoto S, Oda T, Satake M, Seki M. J Colloid Interface Sci 2004;270:221-228. [PubMed: 14693154]

23. Sugiura S, Nakajima M, Iwamoto S, Seki M. Langmuir 2001;17:5562-5566.

24. Sugiura S, Nakajima M, Oda T, Satake M, Seki M. J Colloid Interface Sci 2004;269:178-185. [PubMed: 14651911]

25. Burns JR, Ramshaw C. Lab Chip 2001;1:10-15. [PubMed: 15100883]

26. Gunther A, Khan SA, Thalmann M, Trachsel F, Jensen KF. Lab Chip 2004;4:278-286. [PubMed: 15269792]

27. He MY, Sun CH, Chiu DT. Anal Chem 2004;76:1222-1227. [PubMed: 14987074]

28. Shestopalov I, Tice JD, Ismagilov RF. Lab Chip 2004;4:316-321. [PubMed: 15269797] 
29. Tan YC, Fisher JS, Lee AI, Cristini V, Lee AP. Lab Chip 2004;4:292-298. [PubMed: 15269794]

30. Hibara A, Nonaka M, Hisamoto H, Uchiyama K, Kikutani Y, Tokeshi M, Kitamori T. Anal Chem 2002;74:1724-1728. [PubMed: 12033266]

31. Velev OD, Prevo BG, Bhatt KH. Nature 2003;426:515-516. [PubMed: 14654830]

32. Paik P, Pamula VK, Pollack MG, Fair RB. Lab Chip 2003;3:28-33. [PubMed: 15100802]

33. Wheeler AR, Moon H, Kim CJ, Loo JA, Garrell RL. Anal Chem 2004;76:4833-4838. [PubMed: 15307795]

34. Lenghaus K, Dale JW, Henderson JC, Henry DC, Loghin ER, Hickman JJ. Langmuir 2003;19:59715974.

35. Krishnan M, Burke DT, Burns MA. Anal Chem 2004;76:6588-6593. [PubMed: 15538781]

36. Prime KL, Whitesides GM. Science 1991;252:1164-1167. [PubMed: 2031186]

37. Mrksich, M.; Whitesides, GM. Poly(Ethylene Glycol). 680. ACS Symposium Series; Washington, D.C.: 1997. p. 361-373.

38. Coelho MAN, Vieira EP, Motschmann H, Mohwald H, Thunemann AF. Langmuir 2003;19:75447550 .

39. Sudah OS, Chen G, Chiew YC. Colloids Surf, B 1999;13:195-202.

40. Dickinson E, Matsumura Y. Colloids Surf, B 1994;3:1-17.

41. Song KB, Damodaran S. Langmuir 1991;7:2737-2742.

42. Beverung CJ, Radke CJ, Blanch HW. Biophys Chem 1999;81:59-80. [PubMed: 10520251]

43. Turner SR, Litt M, Lynn WS. J Colloid Interface Sci 1974;48:100-104.

44. Popat KC, Desai TA. Biosens Bioelectron 2004;19:1037-1044. [PubMed: 15018959]

45. Sharma S, Popat KC, Desai TA. Langmuir 2002;18:8728-8731.

46. Papra A, Bernard A, Juncker D, Larsen NB, Michel B, Delamarche E. Langmuir 2001;17:4090-4095.

47. Hu SW, Ren XQ, Bachman M, Sims CE, Li GP, Allbritton NL. Anal Chem 2004;76:1865-1870. [PubMed: 15053645]

48. Chapman RG, Ostuni E, Takayama S, Holmlin RE, Yan L, Whitesides GM. J Am Chem Soc 2000;122:8303-8304.

49. Dimilla PA, Folkers JP, Biebuyck HA, Harter R, Lopez GP, Whitesides GM. J Am Chem Soc 1994;116:2225-2226.

50. Ostuni E, Yan L, Whitesides GM. Colloids Surf, B 1999;15:3-30.

51. Kane RS, Deschatelets P, Whitesides GM. Langmuir 2003;19:2388-2391.

52. Doherty EAS, Meagher RJ, Albarghouthi MN, Barron AE. Electrophoresis 2003;24:34-54. [PubMed: 12652571]

53. Nelson CM, Raghavan S, Tan JL, Chen CS. Langmuir 2003;19:1493-1499.

54. Ostuni E, Kane R, Chen CS, Ingber DE, Whitesides GM. Langmuir 2000;16:7811-7819.

55. Herrwerth S, Rosendahl T, Feng C, Fick J, Eck W, Himmelhaus M, Dahint R, Grunze M. Langmuir 2003;19:1880-1887.

56. Branch DW, Wheeler BC, Brewer GJ, Leckband DE. Biomaterials 2001;22:1035-1047. [PubMed: 11352085]

57. Caelen I, Bernard A, Juncker D, Michel B, Heinzelmann H, Delamarche E. Langmuir 2000;16:91259130.

58. Chapman RG, Ostuni E, Liang MN, Meluleni G, Kim E, Yan L, Pier G, Warren HS, Whitesides GM. Langmuir 2001;17:1225-1233.

59. Chen J, Dickinson E. J Sci Food Agric 1993;62:283-289.

60. Dickinson E, Tanai S. J Agric Food Chem 1992;40:179-183.

61. Harder P, Grunze M, Dahint R, Whitesides GM, Laibinis PE. J Phys Chem B 1998;102:426-436.

62. Mrksich M, Sigal GB, Whitesides GM. Langmuir 1995;11:4383-4385.

63. Ostuni E, Chapman RG, Liang MN, Meluleni G, Pier G, Ingber DE, Whitesides GM. Langmuir 2001;17:6336-6343.

64. Ostuni E, Chapman RG, Holmlin RE, Takayama S, Whitesides GM. Langmuir 2001;17:5605-5620. 65. Prime KL, Whitesides GM. J Am Chem Soc 1993;115:10714-10721. 
66. Yoon JY, Garrell RL. Anal Chem 2003;75:5097-5102.

67. McClellan SJ, Franses EI. Colloids Surf, B 2003;30:1-11.

68. Hernandez EM, Phang TL, Wen XY, Franses EI. J Colloid Interface Sci 2002;250:271-280. [PubMed: 16290663]

69. Dickinson E. ACS Symposium Series 1991;448:114-129.

70. Euston SE, Singh H, Munro PA, Dalgleish DG. J Food Sci 1995;60:1124-1131.

71. Girardet JM, Humbert G, Creusot N, Chardot V, Campagna S, Courthaudon JL, Gaillard JL. J Colloid Interface Sci 2001;243:515-522.

72. Miller R, Fainerman VB, Makievski AV, Kragel J, Grigoriev DO, Kazakov VN, Sinyachenko OV. Adv Colloid Interface Sci 2000;86:39-82. [PubMed: 10798350]

73. Miller R, Fainerman VB, Wustneck R, Kragel J, Trukhin DV. Colloids Surf, A 1998;131:225-230.

74. Ybert C, di Meglio JM. Langmuir 1998;14:471-475.

75. Schultz MM, Barofsky DF, Field JA. Environ Eng Sci 2003;20:487-501.

76. Chechik V, Crooks RM, Stirling CJM. Adv Mater 2000;12:1161-1171.

77. Selve C, Castro B, Leempoel P, Mathis G, Gartiser T, Delpuech JJ. Tetrahedron 1983;39:1313-1316. 78. Hansen FK. J Colloid Interface Sci 1993;160:209-217.

79. McDonald JC, Whitesides GM. Acc Chem Res 2002;35:491-499. [PubMed: 12118988]

80. Matsuoka K, Moroi Y. Curr Opin Colloid Interface Sci 2003;8:227- 235.

81. Tice JD, Lyon AD, Ismagilov RF. Anal Chim Acta 2004;507:73-77. [PubMed: 17186061]

82. Langmuir I. J Am Chem Soc 1918;40:1361-1043.

83. Adamson, AW.; Gast, AP. Physical Chemistry of Surfaces. 6th ed. John Wiley \& Sons; New York: 1997.

84. Fernandez J, Homsy GM. J Fluid Mech 2003;480:267-281.

85. Tronin A, Dubrovsky T, Dubrovskaya S, Radicchi G, Nicolini C. Langmuir 1996;12:3272-3275.

86. Bos MA, van Vliet T. Adv Colloid Interface Sci 2001;91:437-471. [PubMed: 11511044]

87. Hansen FK, Rodsrud G. J Colloid Interface Sci 1991;141:1-9.

88. Graham DE, Phillips MC. J Colloid Interface Sci 1979;70:427-439.

89. Graham DE, Phillips MC. J Colloid Interface Sci 1980;76:240-250.

90. Rampon V, Genot C, Riaublanc A, Anton M, Axelos MAV, McClements DJ. J Agric Food Chem 2003;51:2482-2489. [PubMed: 12696924]

91. Vandervegt W, Vandermei HC, Busscher HJ. J Colloid Interface Sci 1993;156:129-136.

92. Choi KH, Friedt JM, Frederix F, Campitelli A, Borghs G. Appl Phys Lett 2002;81:1335-1337.

93. Hernandez EM, Franses EI. Colloids Surf, A 2003;214:249-262.

94. Nygren H, Stenberg M, Karlsson C. J Biomed Mater Res 1992;26:77-91. [PubMed: 1577837]

95. Tegoulia VA, Rao WS, Kalambur AT, Rabolt JR, Cooper SL. Langmuir 2001;17:4396-4404.

96. McClellan SJ, Franses EI. Colloid Surf, B 2003;28:63-75.

97. Erickson JS, Sundaram S, Stebe KJ. Langmuir 2000;16:5072-5078.

98. Raines RT. Chem Rev 1998;98:1045-1065. [PubMed: 11848924]

99. McComb, RM.; Bowers, GN.; Posen, S. Alkaline Phosphatase. Plenum Press; New York: 1979.

100. Seigel RR, Harder P, Dahint R, Grunze M, Josse F, Mrksich M, Whitesides GM. Anal Chem 1997;69:3321-3328. [PubMed: 9271071]

101. We thank the reviewer for pointing out the importance of the $\Gamma_{\max } / \mathrm{C}_{0}$ ratio in analyzing adsorption. 102. Yoshida M, Tohda K, Gratzl M. Anal Chem 2003;75:6133-6140. [PubMed: 14615992] 103. Song H, Bringer MR, Tice JD, Gerdts CJ, Ismagilov RF. Appl Phys Lett 2003;83:4664-4666. 104. Pollack MG, Fair RB, Shenderov AD. Appl Phys Lett 2000;77:1725-1726. 

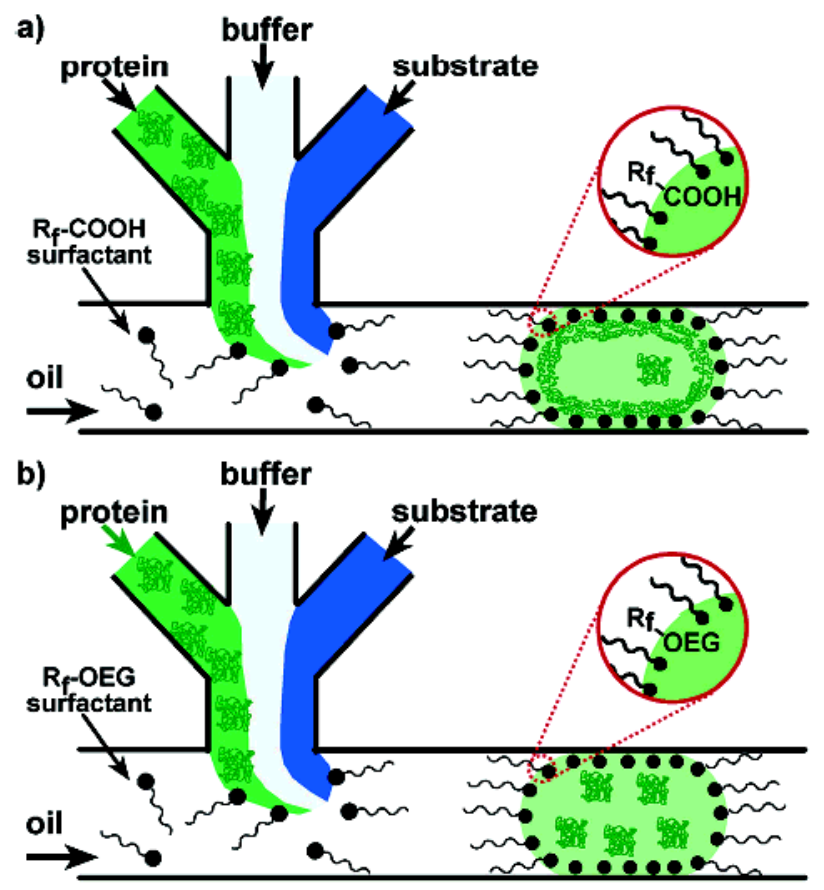

Figure 1.

Controlling surface chemistry in plug-based microfluidic devices with surfactants at the aqueous-fluorous interface. (a, b) Schematic of surfactant molecules at the interface of an aqueous plug of protein in a microfluidic channel. (a) $\mathrm{R}_{\mathrm{f}}-\mathrm{COOH}$ surfactant provided a noninert interface prone to protein adsorption. (b) $\mathrm{R}_{\mathrm{f}}$-OEG surfactant provided an inert, biocompatible interface. 

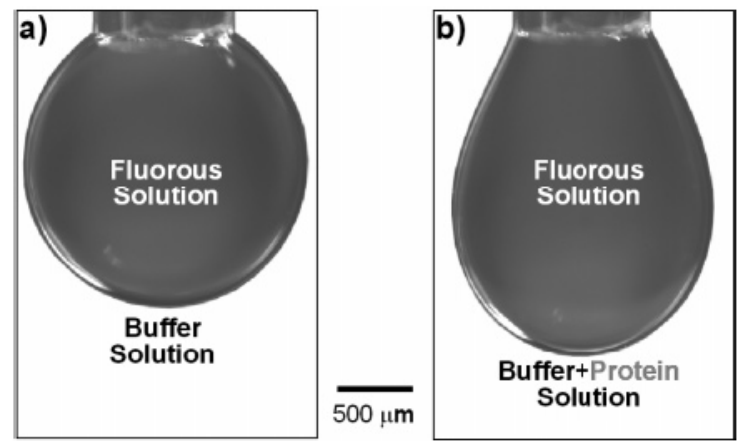

Figure 2.

Using drop tensiometry to detect protein adsorption by measuring surface tension. (a) A spherical droplet indicates high surface tension at the aqueous-fluorous interface. (b) An elongated droplet indicates lowered surface tension at the aqueous-fluorous interface, indicating adsorption of protein to the aqueous-fluorous interface. Both drops are $2 \mathrm{~L}$ in volume. 
a)

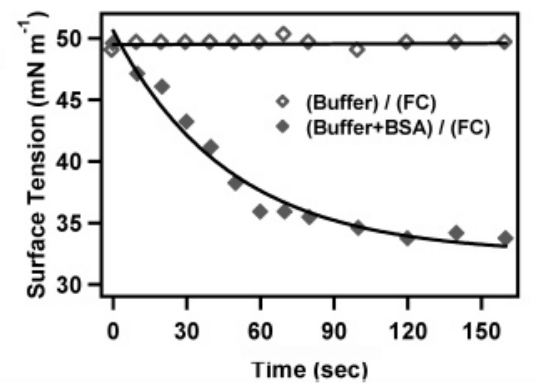

b)

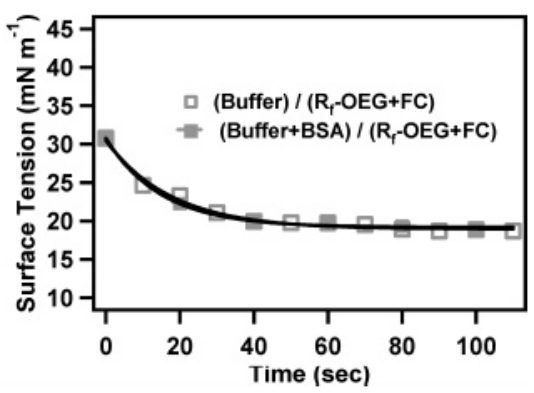

Figure 3.

Graphs of surface tension versus time for BSA at an aqueous-fluorous interface without surfactant $(\downarrow)$ and at an interface that presented the $\mathrm{R}_{\mathrm{f}}$-OEG surfactant (•). (a) BSA adsorbed to the aqueous-FC interface. The surface tension of the (buffer + BSA)/(FC) test droplet ( $\bullet$ was lower than the surface tension of the (buffer)/(FC) control droplet $(\diamond)$. (b) BSA did not adsorb to an interface that presented the $\mathrm{R}_{\mathrm{f}}$-OEG surfactant. The surface tension of the (buffer $+\mathrm{BSA}) /\left(\mathrm{R}_{\mathrm{f}}-\mathrm{OEG}+\mathrm{FC}\right)$ test droplet $(\cdot)$ matched the surface tension of the (buffer) $/\left(\mathrm{R}_{\mathrm{f}}-\mathrm{OEG}\right.$ + FC) control droplet ( $\square$ ). 
a)

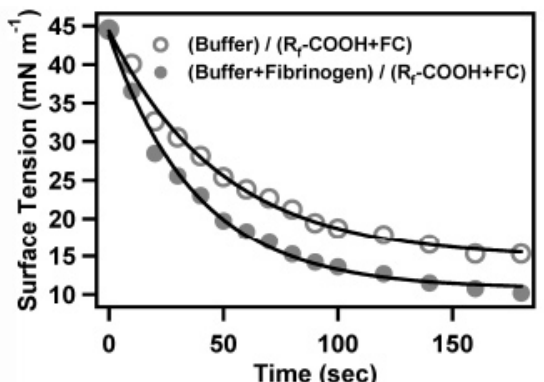

c) $\bar{T} 45-$ (Buffer) /(R,-OEG+FC)

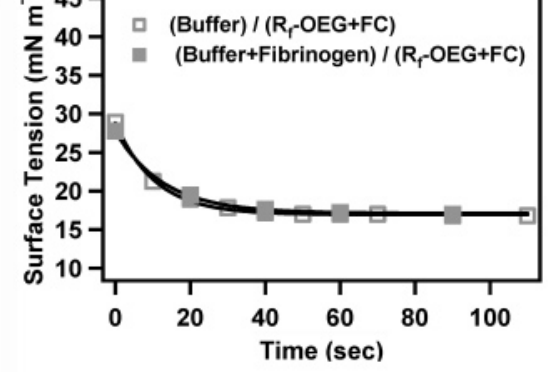

b) $\overline{\mathrm{E}} 16-\triangle$ (Buffer) $/\left(\mathrm{R}_{\mathrm{t}}-\mathrm{CH}_{2} \mathrm{CH}_{2} \mathrm{OH}+\mathrm{FC}\right)$

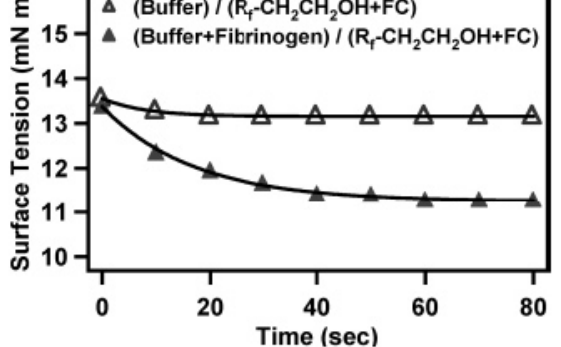

d)

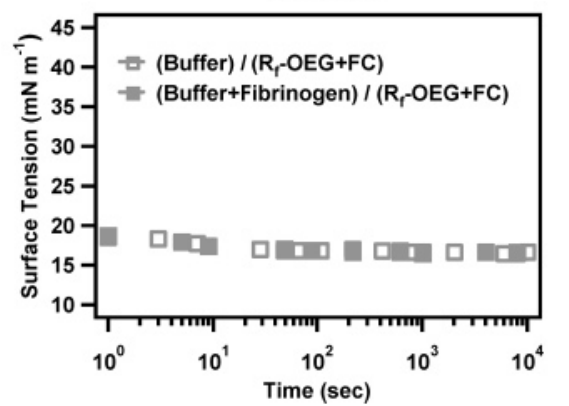

Figure 4.

Graphs of surface tension versus time for fibrinogen at an interface that presented one of the following three surfactants: $\mathrm{R}_{\mathrm{f}}-\mathrm{COOH}(\bullet), \mathrm{R}_{\mathrm{f}}-\mathrm{CH}_{2} \mathrm{CH}_{2} \mathrm{OH}(\bullet)$ or $\mathrm{R}_{\mathrm{f}}-\mathrm{OEG}(\bullet)$. Open symbols indicate (buffer)/(surfactant + FC) control droplets; closed symbols indicate (buffer + fibrinogen)/(surfactant + FC) test droplets. Fibrinogen adsorbed to interfaces that presented either the $\mathrm{R}_{\mathrm{f}}-\mathrm{COOH}$ surfactant (a) or the $\mathrm{R}_{\mathrm{f}}-\mathrm{CH}_{2}-\mathrm{CH}_{2} \mathrm{OH}$ surfactant (b). In (a, b), the surface tension of the test droplet was lower than the surface tension of the control droplet. (c) Fibrinogen did not adsorb to the interface that presented $\mathrm{R}_{\mathrm{f}}-\mathrm{OEG}$. The surface tension of the test droplet matched the surface tension of the control droplet. (d) Concentrated fibrinogen does not adsorb to an interface presenting the $\mathrm{R}_{\mathrm{f}}$-OEG surfactant for times up to $10^{4} \mathrm{~s}$. 


\section{a)}
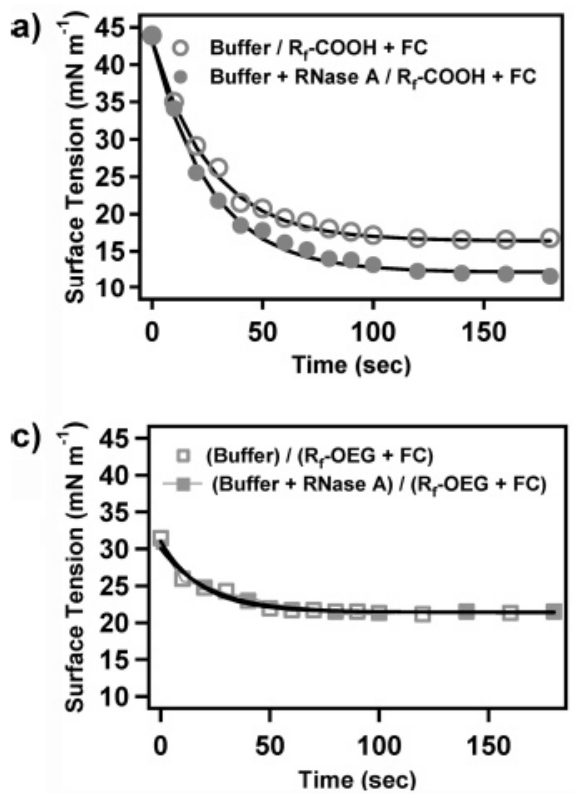

b)

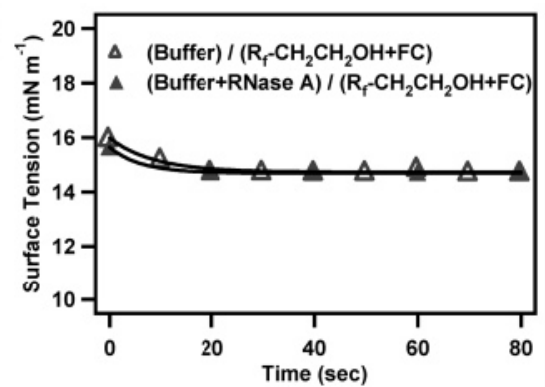

d)

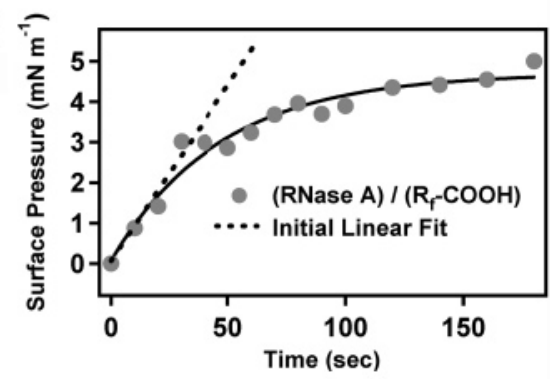

Figure 5.

Graphs of surface tension versus time for RNase A at an interface that presented one of the following three surfactants: $\mathrm{R}_{\mathrm{f}}-\mathrm{COOH}(\bullet), \mathrm{R}_{\mathrm{f}}-\mathrm{CH}_{2} \mathrm{CH}_{2} \mathrm{OH}(\bullet)$ or $\mathrm{R}_{\mathrm{f}}-\mathrm{OEG}(\bullet)$. Open symbols indicate (buffer)/(surfactant + FC) control droplets; closed symbols indicate (buffer + RNase A)/(surfactant + FC) test droplets. (a) RNase A adsorbed to the interface that presented $R_{f}$ $\mathrm{COOH}$. The surface tension of the test droplet was lower than the surface tension of the control. RNase A did not adsorb to interfaces that presented either the $\mathrm{R}_{\mathrm{f}}-\mathrm{CH}_{2} \mathrm{CH}_{2} \mathrm{OH}$ (b) or the $\mathrm{R}_{\mathrm{f}}$ OEG surfactant (c). In (b, c), the surface tension of the test droplet matched the surface tension of the control droplet. (d) The difference in surface tension between (buffer)/(surfactant + FC) controls and (buffer + RNase A)/(surfactant + FC) tests for $\mathrm{R}_{\mathrm{f}}-\mathrm{COOH}(\bullet)$ surfactant was plotted as surface pressure versus time, and a fit was applied to obtain the rate constant for adsorption. 

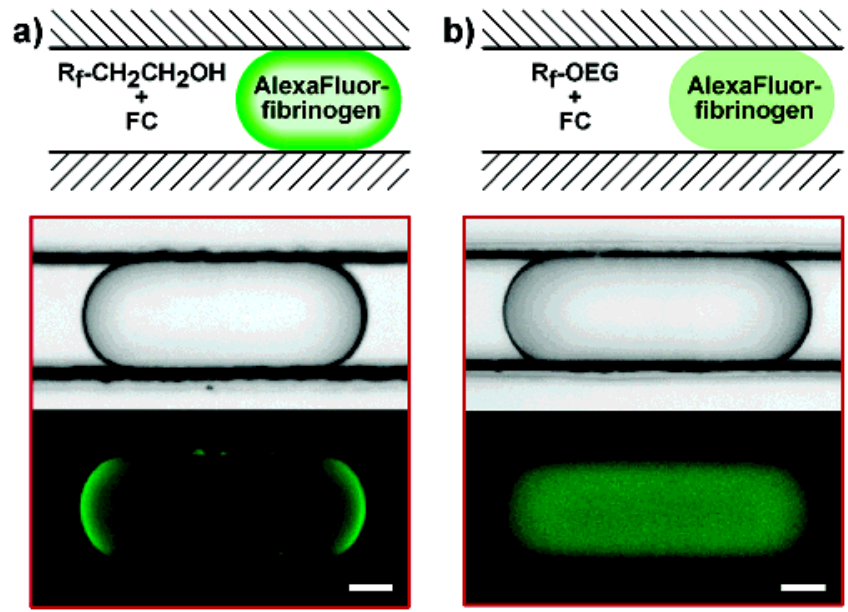

Figure 6.

Qualitative test for adsorption within plugs. Top: schematic drawings of fluorescently labeled AlexaFluor-fibrinogen (95 nM in PBS, pH 7.2) at $\mathrm{R}_{\mathrm{f}}-\mathrm{CH}_{2} \mathrm{CH}_{2} \mathrm{OH}$ (a) and $\mathrm{R}_{\mathrm{f}}-\mathrm{OEG}$ (b) surfaces in plugs based on drop tensiometry results. Bottom: brightfield (left) and fluorescence (right) microphotographs for a (buffer + AlexaFluor-fibrinogen) $/\left(\mathrm{R}_{\mathrm{f}}-\mathrm{CH}_{2} \mathrm{CH}_{2} \mathrm{OH}+\mathrm{FC}\right.$ ) plug (a) and a (buffer + AlexaFluor-fibrinogen) $/\left(\mathrm{R}_{\mathrm{f}}-\mathrm{OEG}+\mathrm{FC}\right.$ ) plug (b). Scale bars are $10 \mathrm{~m}$. (a) Increased fluorescence at the aqueous-fluorous interface indicates fibrinogen adsorption to $R_{f}$ -

$\mathrm{CH}_{2} \mathrm{CH}_{2} \mathrm{OH}$ (b) Uniform fluorescence across the plug indicates that fibrinogen does not adsorb to $\mathrm{R}_{\mathrm{f}}-\mathrm{OEG}$. 
a)
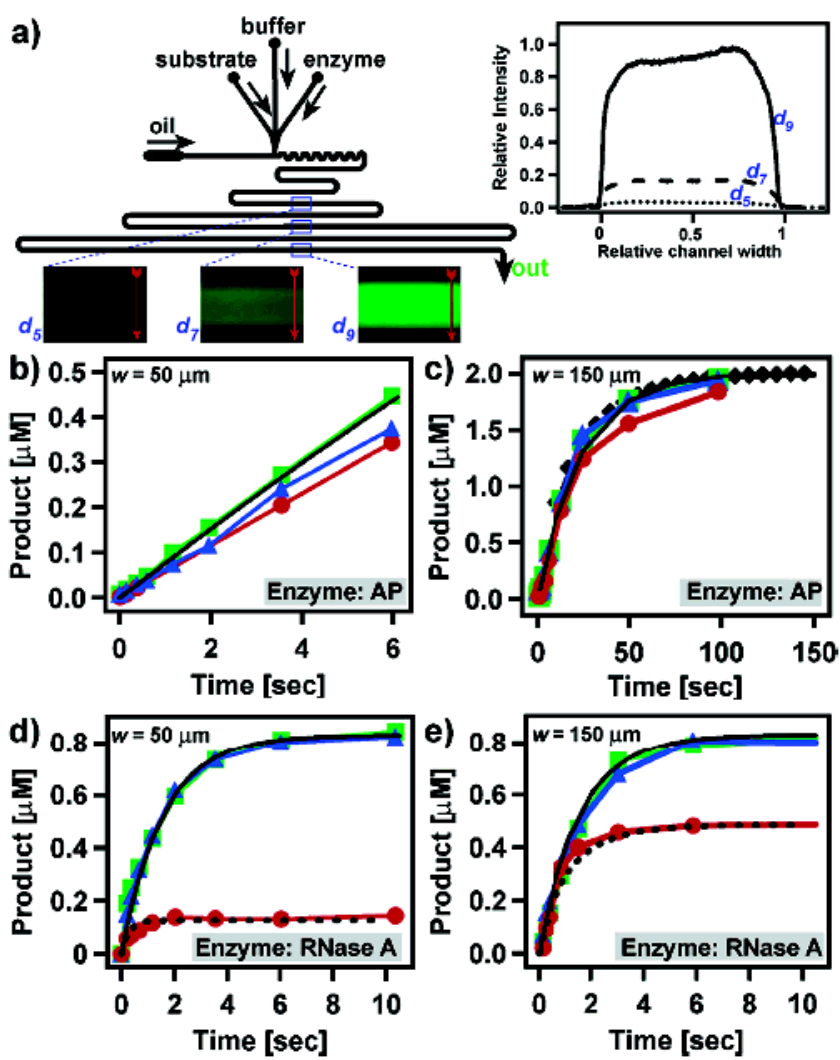

Figure 7.

Quantitative test for adsorption in plugs. (a) Left: A schematic of the microchannel network for measuring exponential enzyme kinetics. The blue rectangles outline the field of view for the false-color fluorescence microphotographs obtained at three micro-channel distances: $d_{5}$, $d_{7}$, and $d_{9}$. Right: Intensity profiles were obtained across the region indicated by the red arrow for each microphotograph. (b-e) Enzyme kinetics was measured within microfluidic devices for $w=50 \mathrm{~m}$ (in b, d) and $w=150 \mathrm{~m}$ (in c, e) for three different surfactants: $\mathrm{R}_{\mathrm{f}}-\mathrm{COOH}(\bullet)$, $\mathrm{R}_{\mathrm{f}}-\mathrm{CH}_{2} \mathrm{CH}_{2} \mathrm{OH}(\bullet)$, and $\mathrm{R}_{\mathrm{f}}-\mathrm{OEG}(\cdot)$. (b, c) Kinetic measurements for alkaline phosphatase (AP). Solid black curves represent expected kinetic curves for fully active AP, obtained from fluorimeter data $(\diamond)$. (d, e) Kinetic measurements for RNase A. Solid black lines represent expected curves for fully active RNase A. Dashed black lines represent numerical fits according to eq 7 and Michaelis-Menten kinetics, where fits were obtained using $k_{\mathrm{a}}=1.4 \times 10^{-2} \mathrm{~mL}$ $\mathrm{g}^{-1} \mathrm{~s}^{-1}(\mathrm{~d})$ and $k_{\mathrm{a}}=0.9 \times 10^{-2} \mathrm{~mL} \mathrm{~g}^{-1} \mathrm{~s}^{-1}(\mathrm{e})$. 